УДК 39 : (477.87) (437.6) (438)

\title{
ЛЕМКІВСЬКА ЕМІГРАЦІЯ У МІЖВОЄННИЙ ЧАС: ПРИЧИНИ, ОСЕРЕДКИ, КУЛЬТУРНА ДІЯЛЬНІСТЬ
}

\section{Наконечний Володимир Михайлович}

кандидат історичних наук,

Київський національний університет культури і мистещтв, м. Київ, Україна

ORCID: 0000-0002-0386-2162

Надіслано:

25.10 .2020

Рецензовано:

11.11.2020

nakonechniy.ua@gmail.com

\section{Прийнято:}

16.11.2020

Мета статті полягає в дослідженні причин і напрямів лемківської еміграції у міжвоєнний час, з'ясування культурно-освітньої праці їі діячів у країнах компактного поселення за матеріалами газет «Наш лемко» та «Лемко». Дослідницька методологія спирається на звичне для праць з історії науки поєднання принципів (історизму та об'єктивності) і методів (філософських, загальнонаукових та спеціально-історичних) наукової праці. Особливо значущими були методика джерелознавчого аналізу (на етапі збору та критики емпіричного матеріалу), а також компаративний i типологічний методи (на реконструктивному та наративному етапах). Наукова новизна статті полягає у спробі цілісної реконструкції причин, напрямів і культурно-освітнього життя лемківської еміграції у міжвоєнний час за матеріалами газет «Наш лемко» і «Лемко». У підсумку проведеного дослідження було доведено, що найбільше русинські газети писали про причини та напрями еміграції, а також висвітлювали життя лемківської діаспори в США, Канаді, Бразилії, Уругваї, Перу та ін. Особливо докладною була інформація про громадське і культурноосвітнє життя закордонних русинів: побудовані культурні установи, проведені концерти та виставки, організовані радіопередачі. Поряд із успіхами, лемківські видання не приховували й труднощів еміграційного життя, викликаних роз'єднаністю та неорганізованістю русинської спільноти на чужині. 3'ясовано, що всі лемківські видання, незалежно від ідейних орієнтацій, були сповнені вдячності на адресу еміграції за її фінансову допомогу краю. Поряд із цим, русинські публіцисти віднотовували й чималі загрози, що їх ніс із собою багаторічний відтік найбільш активної людності. 3 огляду на це, лемківські часописи розгорнули потужну протиеміграційну пропаганду. Вони виховували в русинському середовищі активістське ставлення до життя, переконували лемків ставати ініціативними і кмітливими господарями рідних теренів. Підсумовано, що активне та солідарне обговорення переселенської тематики 
лемківською періодикою сприяло єднанню русинів як на еміграції, так і на батьківщині.

Ключові слова: русини; еміграція; Друга Річ Посполита; «Наш лемко»; «Лемко».

Nakonechnyi Volodymyr, Candidate of Historical Sciences, Kyiv National University of Culture and Arts, Kyiv, Ukraine

\section{Lemko Emigration in the Interwar Period: Causes, Main Communities, Cultural Activities}

The purpose of the article is to study the causes and directions of the Lemko's emigration in the interwar period, to clarify the cultural and educational work of the activists in the countries, the Lemko community settled the most, on the basis of the "Nash Lemko" and "Lemko" newspapers. The research methodology is based on the combination of scientific research principles (historicism and objectivity) and methods (philosophical, general scientific and special-historical), being usual for works on the historical science. Of particularly significance are the methods of source study analysis (at the stage of collection and critique of empirical material), as well as comparative and typological methods (at reconstructive and narrative stages). The scientific novelty of the article is its attempt to comprehensively reconstruct the causes, directions and cultural and educational life of the Lemko emigration in the interwar period based on the materials of the "Nash Lemko" and "Lemko" newspapers. As a result of the study, it has been proved that most Ruthenian newspapers have written about the causes and destinations of emigration, as well as have covered the life of the Lemko Diaspora in the United States, Canada, Brazil, Uruguay, Peru and others. These media explored the social and cultural-educational life of the foreign Ruthenians: cultural institutions, concerts, exhibitions and radio programs. Along with the successes of the community, the Lemko publications did not hide the difficulties of emigration life caused by the disunity and disorganization of the Lemko community abroad. The article finds out that all Lemko publications, regardless of ideological orientation, were grateful to the emigration for its financial assistance to the region. At the same time, the Ruthenian publicists noted the considerable damage of the long-term outflow of the most active population. Therefore, the Lemko newspapers launched a powerful anti-immigration propaganda campaign. They nurtured an active attitude to life in the Ruthenian environment, persuaded the Lemkos to become entrepreneurs and confident owners of their native lands. The article concludes that the active and united discussion of emigration issues by Lemko periodicals contributed to the unification of the Ruthenians both in exile and at home.

Key words: Ruthenians; emigration; the Second Polish Republic; "Nash Lemko"; "Lemko". 
Наконечный Владимир Михайлович, кандидат исторических наук, Киевский национальный университет культуры и искусств, г. Киев, Украина

Лемковская эмиграция в междувоенное время: причины, центры, культурная деятельность

Целью статьи является исследование причин и направлений лемковской эмиграции в междувоенное время, выяснение культурно-просветительской работы ее деятелей в странах компактного проживания по материалам газет «Наш лемко» и «Лемко». Исследовательская методология предполагает привычное для работ по истории науки сочетание принципов (историзма и объективности) и методов (философских, общенаучных и специальноисторических) научного поиска. Особенно значимыми были методика источниковедческого анализа (на этапе сбора и критики эмпирического материала), а также компаративный и типологический методы (на реконструктивном и нарративном этапах). Научная новизна статьи заключается в попытке целостной реконструкции причин, направлений и культурно-просветительской жизни лемковской эмиграции в междувоенное время по материалам газет «Наш лемко» и «Лемко». В итоге проведенного исследования было доказано, что больше всего русинские газеты писали о причинах и направлениях эмиграции, а также освещали жизнь лемковской диаспоры в США, Канаде, Бразилии, Уругвае, Перу и др. Особенно подробной была информация об общественной и культурно-образовательной жизни зарубежных русинов: построенных культурных учреждениях, проведенных концертах и выставках, организованных радиопередачах. Наряду с успехами, лемковские издания не скрывали и трудностей эмиграционной жизни, вызванных разобщенностью и неорганизованностью русинского сообщества на чужбине. Выяснено, что все лемковские издания, независимо от идейных ориентаций, были полны благодарности в адрес эмиграции за ее финансовую помощь краю. Наряду с этим, русинские публицисты отмечали и немалые угрозы, которые нес с собой многолетний отток наиболее активного населения. Учитывая это, лемковские газеты развернули мощную антиэмиграционную пропаганду. Они воспитывали в русинской среде активистское отношение к жизни, убеждали лемков становиться инициативными и сообразительными хозяевами родных территорий. Подытожено, что активное и солидарное обсуждение переселенческой тематики лемковской периодикой способствовало единению русинов как в эмиграции, так и на родине.

Ключевые слова: русины; эмиграция; Вторая Речь Посполитая; «Наш лемко»; «Лемко». 


\section{Вступ}

У міжвоєнний час серед усіх держав Центрально-Східної Європи проблема масової еміграції населення чи не найгострішою була для II Річ Посполитої. Спричинило її величезне аграрне перенаселення, що особливо гостро відчувалося в українських воєводствах, котрі давали більше половини всіх емігрантів молодої польської держави. Про це неодноразово писали українські та польські дослідники. Разом із тим, поза їхньою увагою практично цілковито залишився регіональний аспект еміграційної політики Варшави. Причиною цього $є$ недостатня увага до різнопланової локальної періодики, котра в скількинебудь повній комплектації відклалася лише в поодиноких бібліотечних колекціях. Натомість, як це спробуємо показати нижче на прикладі русинських часописів, дослідження еміграційних процесів за матеріалами періодики у міжвоєнній Польщі уможливить висвітлити не зауважені наразі сюжети. Насамперед, йдеться про нюансування характеру й інтенсивності еміграційних процесів 3 огляду на кліматично-природничі особливості гірських теренів Лемківщини. Чималий інтерес також викликають проблеми адаптації русинів в нових умовах, як також і налагоджене ними в нових місцях проживання культурно-громадське життя. Не менш цікавим $є$ суто русинський погляд на проблему еміграції, що його можна зафіксувати лише опрацьовуючи регіональну пресу. Адже лемківські часописи, що зазвичай видавалися представниками русинської інтелігенції, вели активний епістолярний діалог зі своїм читачем, фіксуючи на шпальтах редагованих газет найбільш значущі для спільноти проблеми. На цих та інших питаннях ми й зосередимося у нашому дослідженні.

\section{Аналіз останніх досліджень і публікацій}

Еміграційна проблематика протягом тривалого часу перебуває у фокусі багатьох досліджень істориків, демографів і соціологів. Серед найбільш вагомих опрацювань останніх десятиліть назвемо праці польських дослідників Анни Речинської, Едварда Колодзєя, Галини Яновської та їхніх українських колег Степана Макарчука та Володимира Трощинського. Спеціально проблемі української еміграції з західноукраїнських земель монографічне дослідження присвятив Степан Качараба (Karachaba, 2003). Згадані історики переконливо довели, що польські уряди тримали еміграційні процеси на особливому контролі, вбачаючи в них чи не єдину можливість зменшення надлишку робочих рук, пожвавлення економіки країни, а також поступової зміни етнічного складу населення українських територій на користь польського елементу. Разом із тим, жоден із названих дослідників не зауважив регіональну специфіку української еміграції з теренів II Речі Посполитої. Цим і зумовлено актуальність теми нашої статті. 


\section{Виділення невирішених раніше частин загальної проблеми}

Важливим завданням сучасної української історіографії $\epsilon$ відтворення регіональної специфіки української еміграції з польської держави на прикладі лемківського субетносу за матеріалами русинських періодичних видань.

\section{Формулювання цілей статті}

Мета статті: дослідити причини та напрями лемківської еміграції у міжвоєнний час, з'ясувати культурно-освітню працю іiі діячів у країнах компактного поселення за матеріалами газет «Наш лемко» та «Лемко».

\section{Виклад основного матеріалу дослідження}

Проблемами лемківської еміграції найбільше цікавилися українофільська газета «Наш лемко» (1934-1939) та ії русофільський відповідник - часопис «Лемко» (1934-1939), чия редакція перебувала у Криниці. Разом із тим, ці часописи 3 різною інтенсивністю зверталися до висвітлення проблем русинської еміграції. Так, якщо редактори «Лемка» писали про них здебільшого в контексті викликів і здобутків переселенського руху, то видавці «Нашого лемка» одразу визначили емігрантське питання як одне з ключових у своїй редакційній політиці, поступово перетворюючи русинську діаспору на органічну складову власної читацької аудиторії. Уже в першому числі газети в кількох програмних редакційних дописах йшлося, що «Наш лемко» писатиме «про житя лемківской еміграції в Гамериці и інших краях» (Pro shcho bude pysaty..., 1934, p. 2), будучи «милою розрадою для кожної лемківської родини на еміграції» (Do nashykh Chytachiv, 1934, p.2). Цієї обіцянки львівська газета послідовно дотримувалася протягом всього періоду видання, постійно збагачуючи спектр обговорюваних питань. 3 огляду на це, ми дещо частіше звертатимемося саме до дописів «Нашого лемка».

Говорячи про причини еміграції, лемківські часописи одностайно вказували на їхню спільність для всіх східних слов'ян - це малоземелля та природне бажання доробитися більших статків у країнах із вищою оплатою фізичної праці. Разом із тим, наголошувалося на суто русинській специфіці, що полягала у швидкому дробленні й так невеликих наділів і складних умовах господарювання на збідненому гористому грунті. Перша обставина була доволі популярним сюжетом на сторінках періодики. Автори дописів на численних прикладах - у художній, публіцистичній і хронікальній формах - показували згубність дроблення земельних наділів у багатодітних лемківських сім'ях. Як відомо, традиційна селянська культура ідеалізувала образ господаря власника земельного наділу, що мало наслідками постійний поділ зазвичай невеликих господарств і нехтування можливостями кооперації. У підсумку більшість русинських родин ледь животіли, спонукаючи своїх дітей шукати джерела заробітку поза звичним колом сільських занять. А оскільки лемківські 
терени оточували регіони здебільшого депресивні в економічному сенсі, чи не єдиною перспективою став виїзд до чужих країн. Лемківський письменник О. Костаревич так описав цю ситуацію: «Половину синів своїх Ти [Лемківщино] вислала за моря шукати долі, бо тісно жити стало» (Kostarevich,1934, р. 3).

Чимало лемківські газети писали і про такий еміграційний фактор як кам'янистість своїх грунтів і суворі умови господарювання на гористих теренах із примхливим кліматом. Це вимагало надмірних затрат праці за зазвичай дуже скромного результату. «Лемко» так змальовував цю проблему: «[...] Земля в горах, населених Лемками, є бідна, мало врожайна, розкидана по цілому хуторі, при цьому тієї землі небагато, через це голод і нужда являються нерідкими гостями в бідних хижах лемківських сіл» (O emihratsii lemkov na Sybir, 1935, p. 2). Відзначимо, що доволі подібні спостереження знаходимо і на сторінках «Нашого лемка».

Згадані негаразди, що стали хронічними супутниками лемківського життя, зродили у русинському середовищі еміграційні настрої одразу після знесення особистої залежності селян в Австро-Угорській імперії. Тож з огляду на вищезгадані некорисні природні умови саме лемки, як про це неодноразово наголошувалося в русинській періодиці, започаткували еміграційні процеси серед українців, торуючи заробітчанські шляхи своїм братам з Галичини, Волині та Закарпаття. Спочатку це була сезонна праця в інших регіонах імперії Габсбургів, а згодом триваліші подорожі до багатших європейських країн. Врешті, русини відкрили для себе країни іншої півкулі, де їм більше прийнятними були умови праці в США та Канаді. Лемківські часописи з певним самовдоволенням одностайно називали саме русинів першопоселеннями на американській землі серед усіх східних слов'ян. Змальовуючи еміграційні поневіряння русинів, «Наш лемко» відзначав: «Незавидна доля казала попрощатися з ріднов земльовй іти в далеки сторони глядати ліпшого житя. I так повандрували наши братя далеко за море до 3'єдинених Держав, Канади, Аргентини, Бразилії, други ж до Франції, Чехословаччини і инших країв» (Do brativ na chuzhyni, 1934, p. 5).

За твердженням русинської преси, протягом др. пол. XIX - поч. XX ст. рідні терени залишило до половини лемківського субетносу. Ефект від цих перших великих еміграційних хвиль для Лемківщини в очах русинських публіцистів був неоціненним. Насамперед, емігрантам своїми переказами коштів вдалося врятувати односельців на батьківщині від крайнього зубожіння, а нерідко й голодної смерті. Іншим вагомим ефектом стало зменшення соціальної напруги на селі, помітне призупинення дроблення земельних наділів. Зрештою, на сторінках лемківських газет наголошувалося на модернізаційних впливах еміграції для лемківського села, адже скитальці нерідко поверталися, привозячи із собою нові ідеї, технології та практики господарювання. 3 огляду на сказане, 
усі лемківські видання, незалежно від ідейних орієнтацій, були сповнені суперлативів на адресу своїх емігрантів. Так, «Лемко» писав: «Не знайдеться на Лемківщині чоловіка, котрий би не вважав еміграцію за річ для нас спасенну і конечну. Лише одна еміграція, а саме до Америки, спасла Лемківщину перед світовою війною і в перших повоєнних роках від чорної нужди» (Emihratsiina komediia, 1936, p. 2). Вповні солідарним із цією позицією був і «Наш лемко»: «Ми [...] високо цінимо нашу заслужену лемківську еміграцію» (Do Vas, Brattiya Lemky, v Amerytsi!, 1934, p. 4).

3 огляду на сказане, стає зрозумілим розпач русинів у 1920-1930-х рр., коли весь світ огорнула небачена перед тим за гостротою економічна криза. Як відомо, іï наслідками стало впровадження багатьма країнами антиеміграційних законів, покликаних обмежити наплив переселенців, даючи працю власним громадянам. Більше того, країни на зразок Франції стали примусово виселяти небажаних емігрантів, серед яких чимало виявилося лемків. Та й ті емігранти, котрим поталанило залишитися, через мізерність заробітків здебільшого не мали можливості допомагати малій батьківщині, що одразу відчули їхні рідні у виснажній економічними негараздами Польщі. Змальовуючи цю критичну ситуацію, лемківські часописи писали: «Перше пускали до Америки, тяжко хлоп працював, у наймах, але як був ощадливий, міг дещо заробити. Америка була для наших бідних газдів великою підпорою. За Австрії ходили наші люди на Венгри на заробіток, тепер через ту границю не пускають. Пускали колись до Франції, але і тут увірвалося. До Канади і Аргентини нема за що виїхати, бо шифкарта дорога. Зрештою і там є досить без роботи. Як бачимо, дуже нам погіршилося через те, що нема куди емігрувати» (Lemkivska bida, abo o tim shcho nas hryze, 1934, p. 3).

У цих умовах лемківська періодика виступила своєрідним порадником для своїх читачів, котрі шукали кращої долі за кордоном. На сторінках газет бачимо різнопланову інформацію стосовно умов еміграції до тієї чи іншої країни, вартості подорожі та їі логістики, можливих небезпек тощо. Особливо ж багато місця відводилося для застережень, викликаних бажанням різномастих шахраїв нажитися на лемківській біді та виманити від довірливих селян останні кошти вигадками про існування «обіцяної землі». Про це промовисто говорять заголовки газетних дописів на кшталт «Проч обманці» чи «Голос перестороги».

Та значно більш важливими були пошуки лемківськими редакторами нових еміграційних теренів для свого нужденного читача. Цю проблему вони вважали однією з першочергових для польської держави: «3 цим всі мусимо рахуватися, це мусять взяти під увагу урядові кола та здійснити старання у держав рідко населених в напрямку отримання колонізаційних теренів і забезпечення місцевому населенню постійної еміграції, щоби таким чином позбутися безробітних на селі, котрих число зростає у застрашаючий спосіб» 
(Bezrabotny na seli, 1935, p.1). Втім, бачення шляхів вирішення цієї проблеми видавцями досліджуваних нами газет різнилося. Так, русофільський «Лемко» популяризував лише ті нові еміграційні напрями, що їх для свого населення пропонували польські уряди. Йшлося, насамперед, про польсько-бразильську міждержавну угоду, за якої польським переселенцям пропонувалися для освоєння 50 тис. га землі у штаті Еспіріту-Санту, де була заснована колонія «Білий орел» (Uslovia prodazhu zemli na kolonii..., 1935, p. 2). У свою чергу, українофільський «Наш лемко» в пошуках нових еміграційних напрямів виходив 3 інтересів самих русинів. У цьому плані на сторінках часопису відверто вказувалося на малопридатні для українців-горян тропічні умови бразильських колоній. Як альтернативу, газета пропонувала вирушати на сезонні роботи до рівнинних українських теренів польської держави, а саме на Волинь і Поділля (Ne emihruite do Slavonii!, 1934, p. 4).

Разом із тим, цілком солідарно львівська і криницька газети виступили проти афери частини американських русинів прорадянської орієнтації, котрі розгорнули голосну агітацію за переселення лемків до Сибіру. 3 цією метою вони популяризували тези книги Сергія Зиніна «Лемковина-Сибир», де на різні лади вихвалялися північноросійські землі як потенційні терени масової лемківської еміграції. Для протидії цим утопічним закликам, котрі знайшли певний відгук у виснажених злиднями лемків, були використані різноманітні медійні інструменти - від переконуючих конкретикою статистично-інформаційних матеріалів до публікації шокуючих уяву зізнань лемків, котрим вдалося вирватися з радянського «раю» (0 emihratsii lemkov na Sybir, 1935, p. 2).

У висвітленні життя лемківської діаспори досліджувані нами часописи фокусувалися на тих осередках, в котрих домінували прихильники їхніх ідейних візій. 3 огляду на це, «Лемко» висвітлював життя русинської громади здебільшого в найдавніших американських і канадських діаспорних поселеннях, куди ще за перших еміграційних хвиль потрапляли симпатики популярної в другій половині XIX ст. русофільської ідеології, котрі й надалі трималися дідівських переконань про «єдину Русь від Карпат до Сибіру». Втім, модернізаційні процеси перших десятиліть XX ст. помітно вплинули на національний вибір лемків, мобільніша частина яких частіше обирала проукраїнську ідентичність. Доказом цього є численні дописи «Нашого лемка», котрий із хронікальною точністю віднотовував розселення лемків багатьма країнами тогочасного світу та інформував про плекання там у міру можливості рідної культури.

Найбільше, звісно, лемківські газети писали про чисельні американські та канадські осередки, з неприхованою гордістю наголошуючи, що «наші Лемки це найстарші Українці-емігранти в Америці» (Tsinne pysmo z Ameryky, 1937, p. 5). 
У часописах навіть було запроваджено самостійні тематичні рубрики, де йшлося про життя русинів у Північній Америці. Важливо, що ці рубрики провадили лемківські кореспонденти на еміграції, завдяки чому читач отримував інформацію з перших рук. Таким чином дописувачі могли сформувати доволі повне уявлення про насиченість культурно-громадського життя своїх побратимів у найкрупніших осередках в Нью-Йорку, Філадельфії, Чикаго, Вінніпезі, Монреалі, Торонто та ін.

У чисельній лемківській діаспорі в США нерідко спалахували ідейні конфлікти, що знайшло відбиття на сторінках материкових газет. Найчастіше йшлося про світоглядні суперечки між прихильниками українофільської та русофільської ідеологій. При цьому обидві сторони закликали до пошуку консенсусу, наголошуючи на шкідливості протистояння (Oi, ne bude tak dobre, Vaniu Huniaka!, 1934, p. 3). Що цікаво, найголоснішим в американській діаспорі був конфлікт, котрий об'єднав ідейних суперників. Так, вповні солідарно вони виступили проти розгорнутої на американському континенті Дмитром Вислоцьким (псевдонім - Ваня Гуняк) нав'язливої радянофільської пропаганди. Редактори «Лемка» та «Нашого лемка» одностайно вказували на небезпеку плекання комуністичних ілюзій у дезорієнтованому економічними негараздами русинському середовищі (Lemky v Amerytsi proty Huniakovoho Lemka, 1935, p. 2).

Поряд зі згаданими країнами, де оселився основний масив русинського субетносу на чужині, доволі багато йшлося про лемківські осередки у південноамериканських країнах - Бразилії, Перу та Парагваї. 3 країн Старого світу домінували дописи про життя русинів у Франції, Німеччині, Британії, Чехословаччині, Литві та Югославії. Уявлення про масштаби лемківської еміграції дають поодинокі дописи 3 далеких Манджурії (Зелений клин) та Австралії. За такої розкиданості лемківської спільноти земною кулею «Наш лемко» навіть запровадив рубрики «Українське життя по всему світу» та «Українське життя на обох півкулях», де робив акценти на становищі русинської діаспори.

Висвітлюючи згадані процеси, лемківські видання одноголосно підносили винятковість адаптативних здібностей русинів. Помітно романтизуючи цю проблему, один із русинських публіцистів писав: «Де не бував би наш рідний брат лемко, він призвичаюється незвичайно скоро до всяких обставин. [...] На рільних роботах у Німеччині, на Уграх і в Франції стає лемко знаменитим рільником. Канадійці захоплені підприємливістю наших братів, за примір їх другим ставлять. Лемківські очі, це чародійні - вистане раз заглянути найбільше складну працю, вже ї руки роблять. Мізок скоренько працює: лемко дає собі раду. 3 піснею іде під землю, до копальні американського вугілля, радісно вигукує при лісових роботах у Канаді, вештається по бразилійських нетрах, залюбки годує домашні тварини серед буйних 
аргентинських степів. Не жалує своїх рук; за це з'єднує собі чужинців, їхні похвали та не найгіршу платню» (Ukrainski lemky nailipshi pratsivnyky, 1935, p. 2). Ми навмисне навели довшу цитату, щоб показати, які риси своєї вдачі самі лемки-емігранти вважали найбільш затребуваними на ринку праці.

Таке наполегливе й ініціативне ставлення до роботи у короткому часі дало помітні результати. Лемківські газети охоче інформували свого читача про культурні здобутки співвітчизників на чужині: побудовані культурні установи, проведені концерти та виставки, організовані радіопередачі тощо. Ці звістки нерідко ілюструвалися фотографіями культурно-просвітних осередків та лемківських активістів. Вповні слушно найбільшої ваги редактори лемківських часописів надавали інформації про інституалізацію українського життя на еміграції. Так, доволі повно висвітлювалася робота Першого з'їзду лемків, який відбувся у Нью-Йорку в серпні 1935 р. Найпомітнішим здобутком цього форумустало створення «Організації оборони Лемківщини» (Zizd lemkiv u Niu Yorku, 1935, p.5). Така громадська зрілість лемків, особливо в осередках їх компактного проживання, поступово перетворювала русинську спільноту на помітного актора суспільно-політичної сцени в США та Канаді. За свідченнями лемківських газет, 3 лідерами русинського руху дедалі серйозніше співпрацювали представники місцевих еліт в надії здобути собі нових виборців.

Поряд із успіхами, лемківські видання не приховували й труднощів еміграційного життя. Слушно вказувалося, що найскладнішою для кожного переселенця $\epsilon$ втрата зв'язку зі своєю батьківщиною. 3 огляду на це, як львівський, так і криницький часописи вбачали своє завдання в тому, щоби слугувати своєрідним посередником між емігрантами та їхньою малою батьківщиною. Найбільш чітко це прозвучало зі сторінок українофільської газети: «Межди емігрантами і Рідним Крайом є духовий зв'язок. Аби тот зв'язок був, як найживіший, повстає «Наш лемко», котрий межи іншим має тот зв'язок зміцняти. Лемківська еміграція, то жива часть рідної Землі» (Do brativ na chuzhyni, 1934, p. 5). 3 огляду на це, лемківські часописи взяли на себе завдання культурної опіки над земляками, що опинилися на чужині. Для них вміщувалися невеликі художні твори та публіцистичні дописи, а також численні ілюстрації визначних природних і культурних пам'яток Лемківщини.

Найбільшою ж проблемою, корені якої містилися в самій еміграції, називалася значна атомізація лемків на чужині, коли заклопотаність щоденними справами ускладнювала усвідомлення потреби національного єднання. Цьому заважали і згадувані нами протиріччя ідейного плану, корені яких сягали ще XIX ст. Утім, молоде покоління лемків 1920-1930-х рр. поступово долало батьківські стереотипи, наголошуючи на потребі солідарного співжиття для осягнення якнайбільших результатів (Oi, ne bude tak dobre, Vaniu Huniaka!, 1934, 
p. 3). Ці консолідаційні зусилля одностайно підтримували й досліджувані нами часописи, намагаючись об'єднати лемків на чужині розумінням певної місії еміграції. Таким вищим сенсом закордонного русинства була визначена близька кожному допомога своєму краю, насамперед фінансова, котра мала піднести лемків не стільки матеріально, скільки культурно. При цьому обидві газети не втомлювалися показувати значущість небайдужості закордонних земляків для єдності лемківського світу: «Віра, що наші Брати за Океаном не забувають про добро Рідних Сторін - перемагає всі труднощі» (Zbirna zhertva nashykh brativ iz-za okeanu, 1936, p. 7).

Поряд із наведеними вище заслуженими суперлативами на адресу лемківської еміграції, русинські публіцисти віднотовували й чималі загрози, що їх ніс із собою багаторічний безупинний відтік найбільш активної людності з гірських теренів. Цікаво, що і в цьому випадку «Лемко» і «Наш лемко», попри нерідко запекле протистояння з більшості світоглядних питань, виявилися вповні солідарними у своїх оцінках. Згадані небезпеки вони розглядали в широкому хронологічному контексті 3 урахуванням специфіки кожної еміграційної хвилі.

Так, уже в перших, найбільше романтизованих лемківським фольклором переселенських потоках, русинські публіцисти вбачали ті тривожні моменти, що згодом стали правдивою загрозою самій екзистенції народу. Йшлося про те, що початкові виїзди з рідних земель мали винятково заробітчанську мету лемки їхали не стільки в пошуках кращої долі, скільки в надії на добрий заробіток, котрий по поверненні мав інтенсифікувати традиційну сільську господарку. Втім, передбачувані терміни перебування на чужині збільшувалися, а самі заробітчани, відчувши переваги нової життєвої ситуації, не поспішали повертатися до своїх домівок. Певне виправдання для себе вони вбачали у постійному фінансуванні родичів на батьківщині. Ті, в свою чергу, доволі швидко звикли до постійних грошевих дотацій, заміняючи активістське ставлення до життя споживацьким. Таким чином утворювалося замкнене коло: заробітчани не могли повернутися, бо вдома постійно очікували на їхню допомогу, а там не бачили сенсу у постійній виснажливій праці, бо ж можна було банально попросити про нову допомогу і жити виключно з неї. Ось, для прикладу, як цю ситуацію змалював дописувач «Лемка»: «До Америки емігрували найздібніші, найвідважніші та наймудріші наші люди. [...] В краю залишався матеріал тяжчий, менше підприємливий, котрий, залишаючись на дідицтві, на батьківській землі, замість того, щоби допомагати тим, котрі емігрували, чекав сам від емігрантів допомоги, тому допомогу отримував, жив 3 неї і писав по нові доляри до Америки, а коли вони тепер перестали напливати, попадає щораз у більшу нужду. Доляри, отже, не зробили того, що могли і повинні були зробити, вони не піднесли наших гір економічно, 
не піднесли господарської культури, а стали джерелом консумаційним, спричинялися до озирання на чужу допомогу і притупили в нас підприємливість і рухливість. 3 цього бачимо, що еміграція з одного боку принесла нашому населенню користі, так і з іншого, виходять і їі злі наслідки» (0 emihratsii lemkov na Sybir, 1935, p. 2).

Ще більшою ця проблема стала у повоєнні роки, адже внаслідок економічної кризи помітно зменшилися фінансові надходження з-за закордону. Тож вкотре найбільш ініціативна та мобільна частина лемків, замість того, щоб шукати можливості покращувати своє життя на місці, вирушала второваною попередніми поколіннями еміграційною дорогою. Але на відміну від перших хвиль, цього разу було очевидно, що з огляду на світову економічну кризу і потребу опановувати нові колонізаційні терени, русини-заробітчани залишають рідний край надовго, а може й назавжди. Це, як твердили лемківські часописи, енергетично знесилює Лемківщину, робить її легкою здобиччю для колонізації іншими народами. 3 огляду на це, «Наш лемко» застерігав: «Масова еміграція лемків [...] дуже пошкодила би нашій Лемківщині. Виїхали би з нашої землі переважно найрухливіші, найвідважніші та здібні й розумні хлопці та дівчата. Населення Лемківщини дуже прорідилося би, а тим часом ми дуже ослабилися б» (Oi, ne bude tak dobre, Vaniu Huniaka!, 1934, p. 3).

3 огляду на це, лемківські часописи розгорнули потужну протиеміграційну пропаганду. Насамперед, вони наголошували на потребі свідомісних змін - відмови від усталеного стереотипу про безальтернативність заробітчанської долі. Пишучи про його надзвичайну шкідливість для самих русинів, «Лемко» у статті під промовистою назвою «Шкідливий спорт» пояснював, що постійними розмовами про еміграцію народ вводиться у стан очікування, в котрому, як відомо, ніхто не хоче забиратися до систематичної праці, бо він мало не завтра «їде геть далеко»; також цим відволікається увага людей від інших пекучих справ і осмислення шляхів покращення соціальноекономічного становища села (Shkodlyvyi sport, 1936, p. 1).

Не менш активно лемківські часописи боролися зі ще одним стереотипним переконанням про виняткову непридатність лемківських теренів для продуктивної сільськогосподарської праці. Вповні слушно наголошувалося, що опанування новітніми техніками обробітку землі взагалі повинно нівелювати цю проблему. А для цього селяни повинні активно зайнятися освітою. «Наш лемко» неодноразово переконував своїх читачів: «Німці мають також кепську землю, в Швайцарії ще вищі гори як у нас, у Фінляндії лиш каміння і болота, проте завдяки високій науці там люде не бідують так як в нас» (Vsiudy dobre, de nas nemaie, 1934, p. 4).

Та найбільше уваги русинські публіцисти присвятили прищепленню лемкам активістського ставлення до життя, поверненню підірваної негараздами 
віри в свої сили. В багатьох публікаціях наголошувалося, що подиву гідні енергія та витривалість, котрі лемки зазвичай демонструють у колоніях, здатні дивовижно перетворити рідні гори. Звідси робився логічний висновок - немає жодної потреби у пошуках гараздів деінде, необхідно просто стати ініціативним і кмітливим господарем рідних теренів. Тож цілу справу переселення, підкреслювали лемківські часописи, не слушно вважати за найважливішу в народному житті; також не можна надавати їй характеру чогось такого, без чого ціла Лемківщина пропаде, бо так не є і нові колонізаційні терени, хоча б і відкрилися, не зможуть значною мірою покращити важкого становища на селі. «Це становище, - наголосив дописувач «Лемка», - поправить лише витривала систематична праця над піднесенням нашої лісної, рільничої та годівляної господарки і в цьому напрямку слід напружити всі наші сили. Не треба жити мріями, що виїдемо в якийсь «медом і вином пливучий край» і не даймося баламутити, бо це знеохочує нас до роботи тут на місці» (Shkodlyvyi sport, 1936, p. 1). Надзвичайно подібну позицію зайняв і «Наш лемко», переконуючи свого читача, що «лише громадною працею, згодою, спільнотою стремлінь [...] відкриємо в себе Америку - обіцяну землю» (Tarnovych, 1935, p. 7).

\section{Висновки}

Як показало проведене дослідження, переселенська тематика була однією з домінуючих на шпальтах лемківської періодики. Таку популярність зумовило першопланове місце еміграції й емігранта у житті русинської спільноти: можливість добрих заробітків у чужому краю відкривали перспективу в нерідко злиденних життєвих обставинах, а сам заробітчанин зазвичай був чи не останньою надією для виснаженого хронічними негараздами односельця. Втім, у короткому часі еміграція як засіб економічної модернізації перетворилася на самоціль, ставши головною загрозою лемківській екзистенції на рідних землях. Тож вповні виправдано русинські часописи ініціювали протиеміграційні настрої: замість пошуку нових «обіцяних» земель вони закликали до їх побудови в рідних горах. Ефект такої агітації $є$ наразі малознаною, але перспективною проблемою для дослідження. Втім, разом iз прийняттям більшістю тогочасних країн протекціоністських законів, ця агітація помітно пригальмувала переселенські процеси. Як відомо, це не вберегло Лемківщину від винародовлення, адже переможці у Другій світовій війні визначили їй зовсім іншу долю.

Перспективним напрямом дослідження $\epsilon$ з'ясування особливостей висвітлення проблем лемківської еміграції на сторінках русинських часописів др. пол. XIX - поч. XX ст. 


\section{References:}

1. 'Bezrabotny na seli' [Unemployed in the countryside]. (1935). Lemko, no. 25(60), p. 1.

2. 'Do brativ na chuzhyni' [To our brothers in a foreign land].(1934). Nash Lemko [Our Lemko], no. 1, p. 5.

3. 'Do nashykh Chytachiv' [To our readers]. (1934). Nash Lemko [Our Lemko], no. 1 , p. 2.

4. 'Do Vas, Brattiya Lemky, v Amerytsi!' [To you, brothers Lemkos, in America!]. (1934). Nash Lemko [Our Lemko], no. 5, p. 4.

5. 'Emihratsiina komediia' [Emigrational comedy].(1936). Lemko, no. 2 (86), p. 2.

6. Karachaba, S. P. (2003). Emihratsiia z Zakhidnoi Urainy (1919-1939) [Emigration from Western Ukraine (1919-1939)]. Lviv: Ivan Franko National University of Lviv.

7. Kostarevich, O. (1934) ‘*****'. Nash Lemko [Our Lemko], no. 1, p. 3.

8. 'Lemkivska bida, abo o tim shcho nas hryze' [The grief of Lemkos or what concerns us most].(1934). Nash Lemko [Our Lemko], no. 1, p. 3.

9. 'Lemky v Amerytsi proty Huniakovoho Lemka' [Lemkos in America versus Huniak Lemkos].(1935). Nash Lemko [Our Lemko], no. 17(52), p. 2.

10. 'Ne emihruite do Slavonii!' [Do not emigrate to Slavonia!].(1934). Nash Lemko [Our Lemko], no. 17, p. 4.

11. 'O emihratsii lemkov na Sybir' [On Lemkos emigration to Siberia].(1935). Lemko, no. 5 (40),p. 2.

12. 'Oi, ne bude tak dobre, Vaniu Huniaka!' [Oh, it won't be that well, Vania Huniaka!]. (1934). Nash Lemko [Our Lemko], no. 17, p. 3.

13. 'Pro shcho bude pysaty "Nash Lemko"' [What is "Nash Lemko" going to write about]. (1934). Nash Lemko [Our Lemko], no. 17, p. 2.

14. 'Shkodlyvyi sport' [A harmful sport]. (1936). Lemko, no. 17(101), p. 1.

15. Tarnovych, Yu. (1935). 'Chy ye za chym zhaluvaty? Chy diisno Ameryka obishchana zemlia' [Is there anything to besorry for? IsAmerica a true «promised land»]. Nash Lemko [Our Lemko], no. 1(25), p. 7.

16. 'Tsinne pysmo z Ameryky' [A valuable letter from America]. (1937). Nash Lemko [Our Lemko], no. 7 (79), p. 5.

17. 'Ukrainski lemky nailipshi pratsivnyky' [Ukrainian Lemkos are the best workers].(1935). Nash Lemko [Our Lemko], no. 6(30), p. 2.

18. 'Uslovia prodazhu zemli na kolonii "Bilyi Orel” v Brazylii' [The conditions of sale of land in Brazilian colony "White Eagle"].(1935). Lemko, no. 24(59), p. 2.

19. 'Vsiudy dobre, de nas nemaie' [The grass is greener on the other side].(1934). Nash Lemko [Our Lemko], no. 9, p. 4. 
Наконечний Володимир Михайлович

20. 'Zbirna zhertva nashykh brativ iz-za okeanu' [Collective sacrifice of our brothers overseas]. (1936). Nash Lemko [Our Lemko], no. 4(52), p. 7.

21. 'Zizd lemkiv u Niu Yorku' [Convention of Lemkosin New York]. (1935). Nash Lemko [Our Lemko], no. 19(43), p. 5.

$\overline{\text { (C)Наконечний }}$ В. М., 2020 